\title{
Orang Kalang Di Pulau Jawa, Tinjauan Historis
}

\section{Diman Suryanto}

Keywords: ethnography, history, tribe, kalang, java, ethnoarchaeology

\section{How to Cite:}

Suryanto, D. (2003). Orang Kalang Di Pulau Jawa, Tinjauan Historis. Berkala Arkeologi, 23(2), 39-50. https:// doi.org/10.30883/jba.v23i2.874

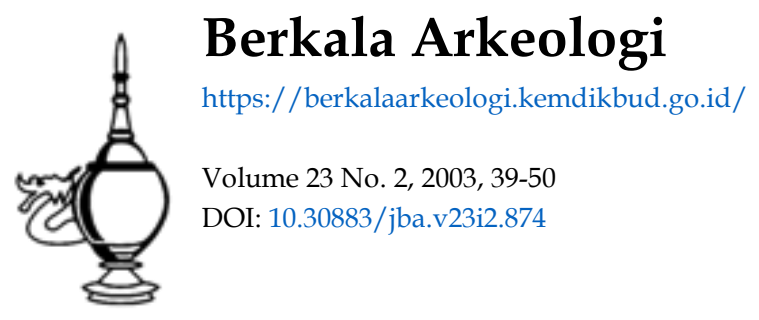

\section{c) (1) (5)}

This work is licensed under a Creative Commons Attribution-NonCommercial-ShareAlike 4.0 International License. 


\section{ORANG KALANG DI PULAU JAWA, TINJAUAN HISTORIS}

\section{Diman Suryanto}

$\mathbf{P}$ ermasalahan

Dalam berbagai prasasti Jawa kuno, banyak sekali dijumpai istilah kalang yang pengertiannya seringkali dihubungkan dengan profesi dibidang perkayuan. . Pengertian tersebut berasal dari suatu realitas terhadap keberadaan orang kalang di masa kemudian, yaitu sekelompok orang yang hidup di hutan di beberapa tempat di Pulau Jawa sebagai penebang kayu.

Kalau kita mengunjungi Yogyakarta dan Surakarta, yaitu daerah bekas kerajaan lama di Jawa Tengah, orang cepat mendengar cerita tentang orang Kalang. Konon mereka mempunyai adat istidat ganjil, menjadi kaya melalui cara yang tidak biasa dan bahkan mempunyai sebuah ekor. Dari gambaran yang tersebar dikalangan masyarakat ini, orang Kalang dianggap berbeda dengan orang Jawa pada umumnya. Anggapan perbedaan ini telah lama ada dan berakar pada masyarakat, sebuah tulisan berbahasa Belanda tahun 1747 telah menyebutkan bahwa mereka dipandang sebagai "suku yang lain".(W. Zwaart : 1939).

Claude Guillot, dalam sebuah seminar tentang golongan-golongan pedagang di Asia, yang diadakan di EHESS, Paris menyatakan bahwa orang Kalang tidak pemah keluar dari Pulau Jawa. Orang Kalang sepanjang sejarah memperlihatkan jiwa kewiraswastaan yang oleh orang barat dulu selalu dikaitkan dengan minoritas asing seperti Tionghoa dan Arab, maka mereka mempunyai tempat dalam penelitian tentang masyarakat dagang dan menyimpulkan bahwa orang Kalang sebagai juru angkut dan banyak pula bergerak dibidang pegadaian (Claude Guillot, 1999).

Daerah-daerah tempat kediaman orang Kalang ialah tersebar disekitar pegunungan yang meliputi daerah utara pantai selatan dan sebelah selatan pantai utara pulau Jawa. Tempat-tempat tersebut diantaranya sebelah selatan ialah: Cilacap, Adipala, Gombong, Ambal, Karanganyar, Petanahan, Yogyakarta, Surakarta, Tulungagung hingga Malang; sedangkan daerah utara diantaranya: Tegal, Pekalongan, Kendal, Kaliwungu, Semarang, Demak, Pati, Cepu, Tuban, Bojonegoro, Surabaya, Bangil dan Pasuruan (Soelardjo Pontjosutirto, 1988)

Di daerah tempat kediaman orang Kalang ini, banyak cerita tentang golongan ini, yang dianggap hina dan sekaligus juga disegani. Mereka konon mempunyai adat istiadat yang ganjil, menjadi kaya melalui cara yang tidak biasa, dan bahkan mempunyai sebuah ekor. Dari gambaran yang ada di kalangan masyarakat ini, jelaslah orang Kalang dianggap berbeda dengan orang Jawa. 
Sebenarnya penampilan mereka sehari-hari tidak berbeda dengan masyarakat Jawa pada umumnya, maka dapat dipertanyakan apa yang membuat mereka lain. Terdapat 4 hal pokok yang membuat mereka lain yaitu : (1) nama Kalang yang dipakai mereka sendiri, (2) mereka tidak menikah diluar kelompok mereka jika ingin menjadi Kalang sejati, (3) mereka bukan (jarang) sebagai petani, dan bekerja sebagai pedagang dan tukang, (4) mereka lama tidak memeluk agama Islam dan mempertahankan ritus-ritus pra Islam dalam hal perkawinan dan kematian (Guillot, Claude, 1999)

Sebagai contoh, pengamatan antropologis khususnya terhadap tradisi atau adat kebiasaan mereka, kita baru dapat membedakan dengan kebiasaan orang Jawa pada umumnya. Karena orang Kalang memiliki tradisi yang khas disebut upacara obong, yaitu upacara kematian, penghormatan terhadap roh leluhur dengan cara membakar puspa atau boneka serta uborampe lainnya, kemudian diteruskan dengan melabuh abunya ke laut atau sungai. Upacara obong yang mengingatkan pada upacara sradha (Majapait) atau Ngaben (di Bali) tersebut, terakhir diselenggarakan pada tanggal 8 Agustus 1978 oleh orang Kalang di desa Ngoto, Kelurahan Bangunjiwo, Kecamatan Sewon, Kabupatren Bantul, Yogyakarta ( M.T. Hari Lelono, 1989).

Terkait dengan kematian masyarakat Kalang, di daerah Bojonegoro dan Tuban terdapat komleks kubur yang oleh penduduk setempat disebut kubur kalang. Bentuknya berupa kubur peti batu yaitu beberapa lempengan batu sebagai dasar, keempat sisinya lempengan batu berdiri dan lempengan batu sebagai penutup (stone cist grave). Tepatnya berada di tengah hutan jati di pegunungan Kendeng Utara, masuk wilayah BKPH Malo. Nama-nama situsnya antara lain di daerah Kabupaten Bojonegoro (situs Kawengan, situs Gunungmas, dan situs Kidangan); dan di daerah Kabupaten Tuban ( situs di Kecamatan Kenduruan dan Kecamatan Senori).

Berdasarkan uraian tersebut di atas masalah penelitian (analisis teoritis) ini adalah apakah orang Kalang yang tersebut dalam prasasti itu identik dengan orang Kalang yang kuburnya (kubur kalangnya) terdapat di daerah Kabupaten Bojonegoro dan Kabupaten Tuban, dan demikiam juga apakah identik dengan orang Kalang yang banyak dikenal dalam masyarakat sekarang.

Demikianlah dalam tulisan ini akan dicoba dibahas pengertian orang Kalang melalui kajian historis. Ini berarti orang Kalang tidak hanya dilihat dari segi pengertiannya, melainkan justru cenderung akan dicoba tentang siapa orang Kalang, dan akan ditarik suatu gambaran historis peranan orang Kalang sebagai kelompok manusia, yang hidup dari jaman ke jaman. 


\section{sal-usul orang Kalang di Jawa.}

Terdapat dua macam uraian mengenai asal-usul orang Kalang. Pertama, uraian bersifat ilmiah dan kedua uraian bersifat cerita rakyat dari mulut ke mulut. Cerita rakyat dari daerah satu dan daerah lainya mempunyai versi yang berbeda. Salah satu dari ceritera rakyat itu sebagai berikut.

Dahulu kala ada seorang raja berburu ke hutan dengan beberapa pengiringnya. Setelah tiba di tengah hutan, raja merasa hendak buang air kecil. Maka dicarinya sebuah tempurung untuk tempat air kencing. Setelah selesai, air kencing dalam tempurung itu ditinggalkan saja di tengah hutan. Pada suatu ketika ada seekor babi hutan betina yang sangat haus dan meminum air kencing raja sampai habis. Tidak lama kemudian babi hutan itu bunting dan setelah waktunya lahirlah seorang bayi perempuam yang mungil. Bayi itu ditinggal saja ditengah hutan dan akhirnya ditemukan oleh seorang janda yang hidup di tepi hutan dan diasuh sebagai anaknya sendiri.

Anak itu akhirnya menjadi gadis yang cantik, yang pekerjaanya menenun kain di atas rumah panggung yang tinggi. Ketika sedang asyik bertenun, mendadak ada alat tenunnya terlepas dan jatuh ke tanah. Ia enggan untuk turun mengambilnya. Agar alat itu kembali, ia mengucapkan nazar, barang siapa yang dapat menyerahkan barang itu, apabila laki-laki akan diterima sebagai suaminya.Tiba-tiba datang seekor anjing jantan yang membawa alat itu. Ia sangat terkejut dan menyesal atas nazamya, tetapi ia tidak mau mengingkari janji nazarnya, dan diambilnya anjing itu sebagai suaminya. Dari perkawinan itu, mereka mempunyai anak laki-laki tampan, yang dinamakan Jaka Sona (anjing). Setelah besar kegemaran pemuda itu berburu dan diikuti oleh anjingya yang setia (sebenamya ayahnya)

Pada suatu hari ketika sedang berburu, berjumpa dengan seekor babi hutan. Ia segera memerintahkan anjingnya untuk mengejar babi hutan itu, tetapi tidak seperti biasanya, anjing itu tidak mau menjalankan perintahnya. Pemuda itu sangat marah, babi hutan dan anjing dibunuh oleh Jaka Sona. Selanjutnya hal itu diceritakan kepada ibunya. Ibunya sangat terperanjat, dengan sedih diterangkan kapada anaknya, siapakah sebenarya babi hutan dan anjing itu. Tidak lain adalah babi hutan itu adalah neneknya sendidiri (nenek Joko Sona) dan anjing itu sebenarnya adalah ayahnya sendiri. Karena merasa bersalah pemuda itu akhimya meninggalkan ibunya mengembara dari hutan ke hutan. Jaka Sona akhimya mengabdikan diri di kerajaan dan terkenal dengan nama Kalangjaya dan dianggap sebagai nenek moyang orang Kalang. Demikianlah salah satu ceritera rakyat atau mitos mengenai asal-usul orang Kalang.

Terdapat beberapa dongeng Jawa versi lain berisi mitos tentang asal-usul orang Kalang, yang digambarkan seperti orang malang yang berpindah-pindah di lingkungan hutan, oleh karena pernah dikutuk setelah melakukan sesuatu yang 
melanggar kaidah alam, seperti perkawinan seorang wanita dengan anjing, babi hutan betina hamil setelah minum air kencing raja dan lain-lain.

Mitos tersebut menimbulkan beberapa kesimpulan seperti: dongeng itu pasti tidak berasal dari orang Kalang sendiri, oleh karena sangat menghina. Apalagi sebagai keturunan anjing, kejijikan orang Jawa Islam terhadap sebutan anjing sebagai makian sangat kasar. Dongeng yang berisi prasangka itu mungkin berusaha mencari sebuah kerendahan sosial bagi orang Kalang.

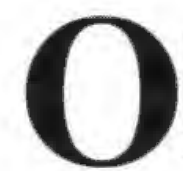
rang Kalang Dalam Prasasti.

Cacatan pertama tentang orang Kalang dalam prasasti berasal dari zaman Mataram pertama (Mataram Hindu) di Jawa Tengah. Istilah kalang muncul pertama kali dalam prasasti Kuburan Candi yang ditemukan di desa Tegalsari, Magelang yang dibuat tahun Caka 753 atau 831 M. pada pemerintahan Rakai Garung. Menurut Goris (1930: 161) istilah kalang tersebut berarti menyatakan jabatan atau profesi dari Kalang sebagai tukang kayu.

Selanjutnya dalam beberap prasasti antara tahun 831-943 M pada umumnya berupa piagam tentang penciptaan sebuah kawasan bebas pajak (sima), tercatat bahwa salah satu persembahan diberikan kepada orang Kalang atau ketua mereka yang disebut dengan istilah Tuha Kalang. Istilah Kalang yang sering pula dilengkapi dengan kata tuha atau tuha kalang yang menyiratkan pada suatu pejabat atau pemimpin kelompok orang Kalang. Di samping itu sering pula diawali dengan kata yang menyatakan profesi yaitu pande kalang (Nastiti, 1982).

Bahkan kalang seringkali dilengkapi dengan nama pejabat dari kelompok orang kalang itu sendiri. Dalam konteks ini, kalang diartikan sebagai pejabat desa yang bertugas di bidang perkayuan. Peranan dan kedudukan kalang cukup penting, contoh tuha kalang sebagai wakil desa tertentu dari kelompok kalang yang seringkali diundang untuk menghadiri upacara penetapan sima. Dalam konteks yang demikian inilah Buchari (1977) mempertanyakan apakah kalang dalam prasasti identik dengan orang kalang pada zaman kemudian, sebab pengertian tukang banyak pula disebut dalam prasasti dengan istilah lain yaitu undagi.

Istilah kalang terus berlanjut pada prasasti-prasasti periode Jawa Timur. Ditemukan lagi piagam tahun $1358 \mathrm{M}$ yang diumumkan oleh raja Majapahit Hayam Wuruk, yang kini dikenal dengan nama 'Piagam Tambang'. Isi piagam tersebut adalah, bahwa "kalau tukang tambang memuatkan sebuah pedati kalang dan kalau muatannya, apapun isinya, jatuh di air, maka tukang tersebut tidak dapat dituntut, namun dia tidak akan menerima imbalan apapun kalau muatan itu hilang". Seringnya istilah kalang 
disebut dalam prasasti, maka sudah tentu peranan dan kedudukan mereka cukup penting.

Sementara itu komunikasi pribadi dengan M.M. Sukarto K. Atmojo yang pernah kita lakukan, mengatakan bahwa pengertian kalang sebenarnya masih kabur. Apakah pande kalang itu sama dengan tuha kalang. Menuru Sukarto kalang dan kalangan juga memiliki pengertian lain, kalangan adalah satu tempat untuk keperluan menyabung ayam, adu ketangkasan untuk suatu upacara tertentu yang di Bali masih di jumpai.

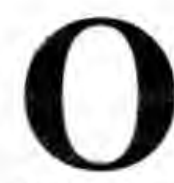

\section{rang Kalang Dalam Masa Mataram Islam.}

Pada masa Mataram Islam, orang kalang muncul beberapa kali dalam pemberitaan. Pada tahun 1636 misalnya Sultan Agung mengumpulkan orang kalang untuk diberi tempat tinggal yang menetap. Orang Kalang dahulu adalah orang yang mengembara di hutan-hutan. Pada masa Sultan Agung mereka disuruh menetap di desa-desa tertentu dan diberi tugas mencari kayu dan menebang pohon di hutan.

Mereka juga diberi tugas sebagai pengangkut barang-barang, kusir pedati, tukang kayu dan lainnya. Karena kemahirannya di dalam pembuatan barang-barang dari kayu, beberapa diantaranya dijadikan abdi dalem atau hamba raja dengan tugas khusus untuk mendirikan bangunan-bangunan di lingkungan keraton seperti masjid, istana, rumah, dan bangunan lain (Altona, 1923).

Di keraton Surakarta, tugas dan kewajiban golongan orang kalang tertuang dalam Anggeran Geladag bab 12-17. Diantaranya mereka berkewajiban menyediakan bahan bangunan berupa kayu jati yang ditebang dari hutan. Di samping mereka mengerjakan bangunan-banguanan keraton, mereka juga melaksanakan pendirian bangunan tempat kediaman putera dan kerabat raja.

Sebagai mata pencaharian pokok, mereka diperkenankan menebang kayu di hutan untuk dijual atau dibuat barang-barang kerajinan. Tetapi mereka juga mendapat kewajiban membayar pajak sebesar satu ringgit yang pada hakekatnya lebih besar dari pajak yang dikenakan pada orang Jawa pada umumnya (Altona, Ibid)

Dari pemberitaan tersebut, memberikan asumsi bahwa orang kalang terpisah dari masyarakat Jawa di sekitarnya. Ada kemungkinan waktu itu kelompok mereka masih tinggal di tepi-tepi hutan, hidup sebagai tukang kayu. Dari kelompok minoritas, masyarakat yang terpisah dari sekitarnya, kemudian dikumpulkan bahkan beberapa diantaranya ada yang diangkat menjadi abdi dalem, jelas ini memperlihatkan perubahan status mereka yang cukup besar. 
Pada abad 18 jumlah orang kalang meningkat. Hal ini terbukti pada tahun 1739 ketika Paku Buwono II mengangkat Sumodiningrat menjadi Tumenggung di Sedayu diberikan tugas pula untuk memerintah golongan kalang yang jumlahnya 6.000 keluarga. Hal ini sesuai dengan waktu ketika diadakan perjanjian Giyanti pada tahun 1755, Susuhunan Surakarta dan Sultan Yogyakarta masing-masing memerintah orang kalang sebanyak 3.000 keluarga (Pontjosutirto, Ibid).

Dari uraian di atas dapat ditarik pengertian, bahwa peranan orang kalang terbukti cukup besar. Kamahirannya dalam bidang perkayuan dimanfaatkan oleh raja untuk mendirikan bangunan keraton sekaligus pembuat berbagai peralatan teknis bahkan termasuk pembuatan perahu. Serat Babad mengeti lelampahan Paku Buwono V memperkuat anggapan itu, bahwa raja mempercayakan pembuatan perahu pesiar yang cukup besar kepada abdi dalem Kalang. Perahu yang besar itu direncanakan untuk dipergunakan mengantar keluarga keraton ke Pamekasan (Serat Babad, 9).

Di keraton Surakarta abdi dalem kalang itu bekerjasama dengan abdi dalem narawreksa. Mereka tinggal di suatu kampung yang hingga kini kampung itu bernama Kalangan. Pada perkembangan selanjutnya abdi dalem kalang dan abdi dalem narawrekso dimasukkan ke dalam suatu jawatan kartipura, yaitu jawatan yang mengurusi bangunan keraton sekaligus bertanggung jawab pada masalah kebersihan dan perawatan bangunan. Di Mangkunegaran jawatan itu bernama Kartisono (Hari Lelono, ibid)

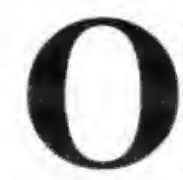

\section{rang Kalang Dalam Masa Kompeni.}

Pada masa Kompeni berkuasa di Jawa, tugas dan peranan golongan orang kalang lebih kompleks dari masa sebelumnya. Kebutuhan Kompeni akan kayu jati untuk membangun kota Batavia dan kota-kota lain, begitu pula untuk kebutuhan galangan-galangan kapal, maka nama kalang tercantum dalam surat-surat resmi atau dagregiter. Bukti tertua surat resmi dari kompeni yang menyebut orang kalang barangkali yang dibuat oleh Jac. Couper dari Jeporo. Dalam surat itu dikatakan antara lain, di hutan-hutan daerah pegunungan Rembang dan Pati ada sejumlah orang kalang yang mahir dibidang perkayuan.

Dari berita tersebut dapat diketahui, bahwa pada waktu itu terdapat banyak golongan orang kalang yang berdiam di sekitar hutan sebagai penebang kayu. Kemampuan mereka dalam bidang perkayuan dimanfaatkan oleh kompeni untuk pembuatan berbagai sarana guna memperkokoh kekuasaannya di Jawa.

Pencatatan yang pertama oleh orang Belanda, tahun 1675 menampilkan orang kalang di daerah Rembang dan Pati , Jawa Tengah sebagai penebang pohon dan mahir di bidang perkayuan sepeti tersebut di atas. 
Tiga tahun kemudian (1678), berdasarka memori Speelman bahwa kesediaan golongan orang kalang mendapat rintangan dari pemimpin mereka. Mereka tidak diperbolehkan menyerahkan kayu kepada pihak kompeni. Maka terpaksa pihak kompeni minta bantuan kepada Susuhunan agar berkenan turun tangan, tetapi usaha tersebut tidak membawa perubahan, bahkan Susuhunan berpihak kepada golongan orang kalang.

Satu bukti bahwa golongan orang kalang tidak mau berkerja sama dengan kompeni, tercantum dalam Dagregister tanggal 22 Oktober 1680 yang menerangkan, bahwa mereka segan bekerjasama dengan kompeni dengan alasan takut mendapat hukuman badan dari pimpinan mereka.

Keadaan nasib orang Kalang mengalami perubahan lagi ketika tahun 1743 diadakan perjanjian antara Susuhunan Paku Buana II dengan pihak Kompeni berhasil mengakhiri suatu pemberontakan. Dalam perjanjian itu diantaranya ditetapkan bahwa orang Jawa tetap diperintah oleh bupati-bupati, sedangkan orang golongan kalang merupakan golongan terpisah dari masyarakat Jawa pada umumnya. Selain itu para Bupati diwajibkan mengirim sejumlah orang kalang yang diperlukan oleh kompeni untuk pembuatan maupun perbaikan kapal-kapal di galangan-galangan kapal (de Yonge, 1875 ; B. Sulistyanto, 1994).

Penyajian keterangan yang lebih luas mengenai orang kalang, adalah bahwa, orang kalang sebagai penebang pohon, pengangkut kayu, pembuat 'gorab' (gerobag) dan kapal perang. Mereka mempunyai sejumlah ketua satu diantaranya bergelar Tumenggung.

Pada tahun 1679 orang kalang dipakai untuk tenaga mengangkut barang oleh tentara Hurdt (tentara Belanda) yang pergi menyerang Trunojoyo di Kediri. Setelah pesisir Jawa Utara dikuasai oleh Belanda pada tahun 1743, maka tiga tahun kemudian pada tahun 1747 Kompeni mengakui status khas orang kalang sebagai golongan sendiri (een apart volk) yang mempunyai ketua sendiri, lain dengan orang Jawa pada umumnya. Mereka diwajibkan membayar pajak yang sebelumnya pajak tersebut dibayarkan mereka kepada raja Jawa sebagai orang asing. Pajak tersebut pada akhirnya dihapuskan oleh Daendels, yang selanjutnya memberikan hak menebang pohon kepada orang kalang "yang membuat tjekat (cikar) dan pedatten (pedati.) yakni jenis gerobak Jawa".

Yang pertama menyajikan sejenis penelitian tentang orang kalang adalah Raffles, dalam bukunya History of Java. Raffles menerangkan bahwa mereka (orang kalang) baru hidup menetap. Sebelumnya mereka terus menerus berjalan dari satu daerah ke daerah lain, naik pedati yang beroda dengan poros berputar, yang ditarik oleh 2 pasang sapi atau lebih. Mereka memuat bahan-bahan bangunan untuk gubuk mereka, 
serta perabot pertanian dan semua bahan keperluan dan barang berharga (Raffles, 1817: jil. I, 327-329).

Pada tahun 1839, Winter Sr. mencatat bahwa pada zaman dahulu mereka (orang kalang) suka berpindah-pindah. Selanjutnya pertengahan abad 19 terbit berbagai tulisan dari orang Belanda mengenai orang kalang antara lain seperti tersebut di atas.

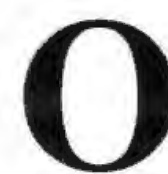

\section{rang Kalang Masa Sekarang}

Keberadaan orang kalang pada masa sekarang sukar diketahui. Sebab mereka sudah berbaur dengan masyarakat Jawa pada umumnya. Golongan orang kalang memiliki sifat mudah menyesuaikan diri dan bersifat terbuka. Kedudukan mereka tidak sejelas golongan orang Tengger di Jawa Timur atau orang Badui di daerah Banten Jawa Barat misalnya, yang hidup mengelompok memisahkan diri dari masyarakat yang beragama Islam. Kedua golongan itu masih merupakan kesatuan masyarakat tersendiri dan masih tetap mempertahankan adat istiadat nenek moyang mereka.

Orang kalang pada mulanya mempunyai adat istiadat sendiri yang khas, namun lama kelamaan luntur dan menyesuaikan diri dengan kebudayaan milik masyarakat sekitar. Mereka menyesuaikan diri dalam bidang agama, mata pencaharian, bahasa, cara berpakaian, pemanfaatan teknologi dan lainya. Orang kalang sudah bercampur dan berasimilasi dengan masyarakat sekitar. Mereka menikah dihadapan penghulu, memeluk agama Islam, mengkhitankan anak-anaknya, mengubur yang meninggal secara Islam, dan lainnya.

Namun demikian, terdapat satu hal yang masih dipertahankan yaitu tradisiaatau adat istiadat. Tradisi yang khas inilah yang membedakan antara orang kalang dengan orang Jawa pada umumnya. Tradisi dimaksud adalah upacara obong yaitu upacara yang diadakan pada hari ke 1000 setelah kematian seseorang (nyewu) Upacara ini bertujuan untuk menghormati roh leluhur dengan cara membakar puspa (sarira) dan perlengkapan sasaji atau uborampe lainnya. Dan selamjutnya abu dari puspa dan perlengkapan serta uborampe lainnya di labuh atau dihanyutkan ke sungai atau laut.

Upacara obong demikian mirip dengan upacara sradha pada masa Majapahit, sebagaimana diceritakan dalam Negarkertagama pupuh 62-67 (Slametmulyono, I979). Terdapat tiga hal pokok yang menunjukkan kemiripan dalam kedua upacara tersebut.

Pertama, adanya puspa(sarira), yaitu boneka sebagai simbol roh si mati. Dalam upacara obong puspa dibuat dari kayu jati tanpo soco (kayu jati yang tidak cacat atau bermata) dengan tinggi sekitar $35 \mathrm{~cm}$ dan lebar $15 \mathrm{~cm}$ dilengkapi dengan pakaian dan 
perhiasan sebagaimana layaknya manusia hidup (Hari Lelono, ibid). Sedangkan dalam upacara sradha (masa Majapahit), puspa atau simbol si mati dibuat dari rangkaian bunga.

$K e d u a$, adanya pancaka, yaitu bangunan rumah-rumahan dibuat dari rangka bambu berdinding dan beratap daun ilalang, berukuran tinggi 1 meter dan luas $2 \times 2$ meter. Bangunan ini untuk menyemayamkan puspa sebelum akhimya dibakar dan abuya dibuang ke laut.

Ketiga, proses jalannya ritual dalam upacara obong dilakukan dengan mengkirikan bangunan pancaka atau disebut prasawya, suatu ritual klasik berkaitan dengan upacara kematian.

Upacara obong yang dipertahankan oleh orang kalang, terakhir dilaksanakan pada tanggal 8 Agustus 1978 oleh orang kalang di Desa Ngotho, Kalurahan Bangunjiwo, Kecamatan Sewon , Kabupaten Bantul, Propinsi D.I. Yogykarta (Hari Lelono, 1989). Dari upacara obong tersebut dapat dijelaskan bahwa, antara lain secara pisik orang kalang sukar dibedakan dengan orang Jawa, namun secara kultur masih dapat diamati. Ciri-ciri orang kalang antara lain: rumah mereka berpagar tinggi, gemar memelihara anjing, senang memakai nama Mulyo atau Perwiro, kebanyakan bekerja sebagai wiraswasta (Buchari, 1985). Kehidupan mereka pada umumnya berkecimpung dalam bidang usaha dan perdagangan. Mereka ahli dalam dalam bidang usaha batik, tenun, barang-barang dari perak, jarang diantara mereka yang menjadi pegawai negeri atau tentara. Hubungan diantara mereka sangat erat, begitu pula kesadaran untuk saling membantu diantara mereka sangat kuat (Poncosutirto, Sulardjo; ibid).

Selanjutnya ciri orang kalang yang lain adalah mereka menganut endogami. Terutama pihak laki-laki warga Kalang harus mencari jodoh dari orang kalang sendiri. Bagi yang perempuan ketentuan mendapat suami orang Kalang agak longgar.

Melihat situasi hari ini, boleh dikatakan bahwa orang Kalang sama dengan orang Jawa pada umumnya. Mereka masuk agama Islam dan mereka meninggalkan ritus leluhurnya (meskipun dengan beberapa pengecualian). Meskipun demikian mereka mengaku, sebagai anggoata dari suatu minoritas, sebagai pelanjut suatu tradisi dan juga merasakan diri sebagai satu kelompok elite.

Dari segi lain, golongan tersebut memasang sejumlah syarat bagi anggotanya, agar mempertahankan keaslian Kalangnya. Pertama, seorang warga Kalang harus mengawini saudara sepupunya atau paling sedikit sesama orang Kalang. Syarat ini semakin sering diabaikan selama beberapa dasawarsa ini, sehingga membahayakan kelangsungan hidup golongan tersebut. Kedua, seorang warga Kalang harus mempunyai jiwa wiraswasta, dan memiliki sifat menghormati keluarga dan tradisi, 
mengutamakan solidaritas golongan, bergaya hidup ketat dan terutama bersifat rajin, jujur dan disiplin.

Orang yang mengabaikan syarat yang khas kaum dagang ini, akan tersingkir tanpa ampun dan dianggap bukan anggota golongan orang kalang lagi. Dengan kata lain , seseorang medapat identitas Kalang dari kelahirannya, dan mempertahankan sebagai warga Kalang atas kemauannya sendiri.

Pada umumnya kebanyakan pemuda Jawa berkeinginan menjadi pegawai negeri (kantor), guru atau tentara, namun pemuda Kalang hanya mau menjadi pengusaha. Sikap orang Kalang dapat dipahami, utamanya sifat kewiraswastaannya dianggap sebagai satu ciri khas yang sekaligus merupakan identitas. Ciri khas ini, seperti ciri khas satu minoritas lain, seperti orang Tionghoa. Mereka selalu berusaha agar diakui keberadaannya melalui sukses materi. Oleh karena seseorang Kalang yang menjadi petanipun berkewajiban menghasilkan panen yang lebih besar dan lebih baik dari orang Jawa di desa lainnya.

Tradisi mereka yang panjang sebagai juru angkutan, disimpulkan oleh Claude Guillot sebagai mempertalikan usaha mereka antara dunia dagang dan pertukangan (Guillot, ibid). Kegemaran sementara orang Kalang meminjamkan uang dapat dicari beberapa alasan. Kegiatan ini sebenarnya termasuk kegiatan dagang pada umumnya. Di linghkungan desa yang jarang tersentuh peredaran uang seorang pedagang atau meminjamkan uang menjadi lancar dan lebih mudah mencari uang dari pada petani. Orang kalang suka menabung dan penampilan hidupnya sangat sederhana dan sifat hemat merupakan ciri khas golongan mereka.

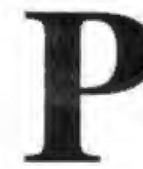

enutup

Dari berbagai informasi yang serba sedikit ini, dapatlah kiranya ditarik kesimpulan mengenai orang Kalang di Jawa sebagai berikut: Pertama, sudah jelas mereka merupakan sebuah golongan tersendiri dengan ketua-ketuanya (tuha kalang) Kedua, mereka lama menganut adat istiadat pra-Islam. Ketiga, mereka mempunyai status tersendiri dan diwajibkan membayar pajak khusus. Keempat, pada abad 17 dan 18 digambarkan sebagai tukang tebang pohon dan tukang kayu. Kelima, pada abad 19 beberapa buku pegangan tentang perkayuan diterbitkan dengan judul 'ilmu kalang' (kawruh kalang). Keenam, mereka bersifat pengembara yang agaknya berakhir secara bertahap pada abad 17 dan 18. Ketujuh, pedati atau cikar yang terus disebut-sebut dalam berbagai tulisan tentang orang kalang sampai awal abad 19 seperti juga dalam dongeng (Ketjen, 1877). Kedelapan, orang kalang adalah juru angkutan di Jawa pada masa kuno. 
Kesimpulan ini kiranya dapat menerangkan semua data dan informasi yang ada. Sifat mengembara disebabkan oleh perjalanan panjang di atas pedati yang ditarik oleh 2 pasang sapi atau lebih, oleh karena sangat lama dan tidak memungkinkan mempunyai tempat tinggal tetap. Mereka akrab dengan lingkungan hutan karena melintasinya atau malah tinggal di dalam hutan selama perjalanan.

Sejenis monopoli yang mereka peroleh adalah untuk membuat pedati. Maka wajarlah bagi mereka menjadi penebang dan mengerjakan kayu. Monopoli mereka atas angkutan di jalan, dapat menjelaskan sikap endogami mereka (kawin-mawin dalam golongan sendiri). Akhimya, kehidupan mengembara di hutan rimba, merupakan dasar sikap curiga dari golongan petani, serta alasan kenapa mereka lambat menganut agam Islam dan mereka segan menggarap tanah.

Bukti lain yang memperkuat kesimpulan tersebut adalah kalau kita mengamati tempattempat mereka beraktivitas yang akhimya menetap. Berdasarkan dokumen abad 18 dan 19 tampaklah tempat itu terletak di dua garis Pulau Jawa yaitu di utara (Pekalongan ke timur sampai Banyuwangi) dan di selatan (dari Banyumas ke arah timur sampai Malang). Kedua garis ini akhimya bertemu di Sungai Brantas, hal ini mungkin sekali merupakan jalur perjalanan mereka pada masa lalu.

Untuk menggambarkan keberadaan orang kalang yang sudah menetap, pada tahun 1744 (zaman Kartasura) terdapat pejabat yang diberi tugas khusus mengepalai golongan masyarakat tertentu. Jabatan itu dipegang oleh 4 orang Tumenggung, salah satunya Tumenggung yang mengepalai 6.000 orang Kalang. Golongan-golongan lainnya adalah golongan orang Gowong sebanyak 1.000 orang (beraal dari daerah Bagelen), golongan Tuwaburu sebanyak 1.200 orang (pegawai raja yang pekerjaanya menangkap hewan termasuk harimau atau berburu), dan golongan Kadipaten sebanyak 1.400 orang

Orang Kalang, adalah arang-orang yang mengembara di hutan-hutan. Pada masa Sultan Agung mereka disuruh menetap di desa-desa tertentu dan diberi tugas mencarai kayu dan menebang pohon di hutan. Mereka juga diberi tugas sebagai pengangkut barang-barang, sebagai kusir pedati, tukang kayu dan lainnya. Pada zaman Palihan Negari (Gijanti), Kerjaan Sala dan Jogya masing-masing mendapat 3. 000 somah orang Kalang (T. Altona, 1923). 


\section{KEPUSTAKAAN}

Altona. T, 1923. "Over de Oorsprong der Kalang", TBG, Batavia, den Haag, Albreht \& Co, M. Nijhoff, jil. LXII

Buchari, 1977. Aspek Keagamaan dan Adat Dari Upacara Obong Pada Orang Kalang di Desa Ngoto. Laporan Pengembangan Ilmu Pengetahuan dan Teknologi, Yogyakarta, Belum terbit.

Goris R, 1930. "Inscriptie Koeboeran Candi", TBG, Batavia Redactie p.a. Museum, Koninksplein W. 12, jil. LXX.

Eerde . J.C.van, 1902 "De Kalang legende op Lombok", dalam TBG, Jil. XLV

Guillot, Claude, 1999. “Orang Kalang di Pulau Jawa, Jura Angkut dan Pegadaian", dlm Panggung Sejarah, persembahan kepada Prof. Dr. Denys Lombard, ed Henri Chambert-Loir, Hasan Muarif Ambary, Puslit Arkenas, Ecole francaise d' Extreme-Oriernt : Yayasan Obor Indonesia. hlm 323-334

Lelono, H. (1989). Upacara Kalang Obong (Suatu Tinjauan Etno-Arkeologi). Berkala Arkeologi, 10(1), 1-9. https://doi.org/10.30883/jba.v10i1.533

Jonge, J.K. 1875. De Opkomst van het Nederlandsch Gezag in Oast Indie.'s Gravenhage : M.Nijhoof.

Knebel. J. 1894. "De Kalang Legende, volgens Tegalsche lezing. Uit het Javaans," dalam TBG jil. XXXVII.

Nastiti, Titi Surti, dkk., 1982. Tiga Prasasti Dari Masa Balitung. Jakarta: Pusat Penelitian Arkeologi Nasional.

Pontjosutirto, Sularjo, 1988. Beberapa Hal Mangenai Orang Kalang, Makalah pada ceramah di Museum Sonobudoyo, Yogyakarta.

Sukarto K Atmodjo, 1986. Data Undagi Dalam Prasasti Kune, dalam Diskusi llmiah Arkeologi, Yogyakarta.

Slametmulyana, 1977. Nagarakertagama dan Tafsir Sejarahnya, Jakarta : Bratara

Veth P.J. 1907. Java, Geographisch, Ethnologisch, Historich, Batavia

Zwaart, W, 1939. “ De Kalangs als houtkappers, indienst der Compagnie”, TBG 79 